\title{
Radon content in Danish till deposits: relationship with redox conditions and age
}

\author{
Peter Gravesen and Peter Roll Jakobsen
}

Radon $\left({ }^{222} \mathrm{Rn}\right)$ is a radioactive, noble insoluble gas with a half-life of 3.8 days. It belongs to the uranium $\left({ }^{238} \mathrm{U}\right)$ decay chain where radon is formed from radium $\left({ }^{226} \mathrm{Ra}\right)$. Uranium and radium are built into mineral structures or are, for example, adsorbed on the surface of clay minerals, limonite or organic material. When radon is formed by radioactive decay from radium, parts of it enter the pores of rocks and soils and are transported by diffusive or advective forces in the pores. The transport rate depends on the permeability and water content in the pores (Nazaroff 1992).

Radon may enter into buildings through fractures in the walls driven by forces such as pressure gradients between the outside and the inside. Radon and its radioactive decay products are inhaled by living beings and are the main source of radiation to which humans are exposed. The radiation presents an increased risk of lung cancer and may cause leukaemia, which mainly occurs in children. On the basis of risk analyses it has been estimated that $10 \%$ of all cases of lung cancer in Denmark are caused by radon inhalation (Sundhedsstyrelsen 1987). It has been demonstrated that rocks and soils around and below houses are the main sources of radon emanation.

Several studies have analysed and described the radon content in Dan-
Fig. 1. Simplified geological map of Denmark, showing the general distribution of surface lithologies, the most important icemargin lines from the Weichselian and the four investigated localities. ish sediments and rocks (e.g. Damkjær \& Korsbech 1985; Gravesen et al. 1996) and have demonstrated its relationship to radon levels in Danish buildings (Andersen et al. 2006; Raaschou-Nielsen et al. 2008). A nation-wide mapping of radon levels in Danish dwelling houses based on, e.g. mapping of Quaternary surface deposits and information about radon in sediments and rocks was performed by Andersen $e t$ al. (2001).

This paper presents some results concerning the radon content and emanation rates in different Danish till deposits of Saalian and Weichselian age from a study carried out by the Geological Survey of Denmark and Greenland (GEUS).

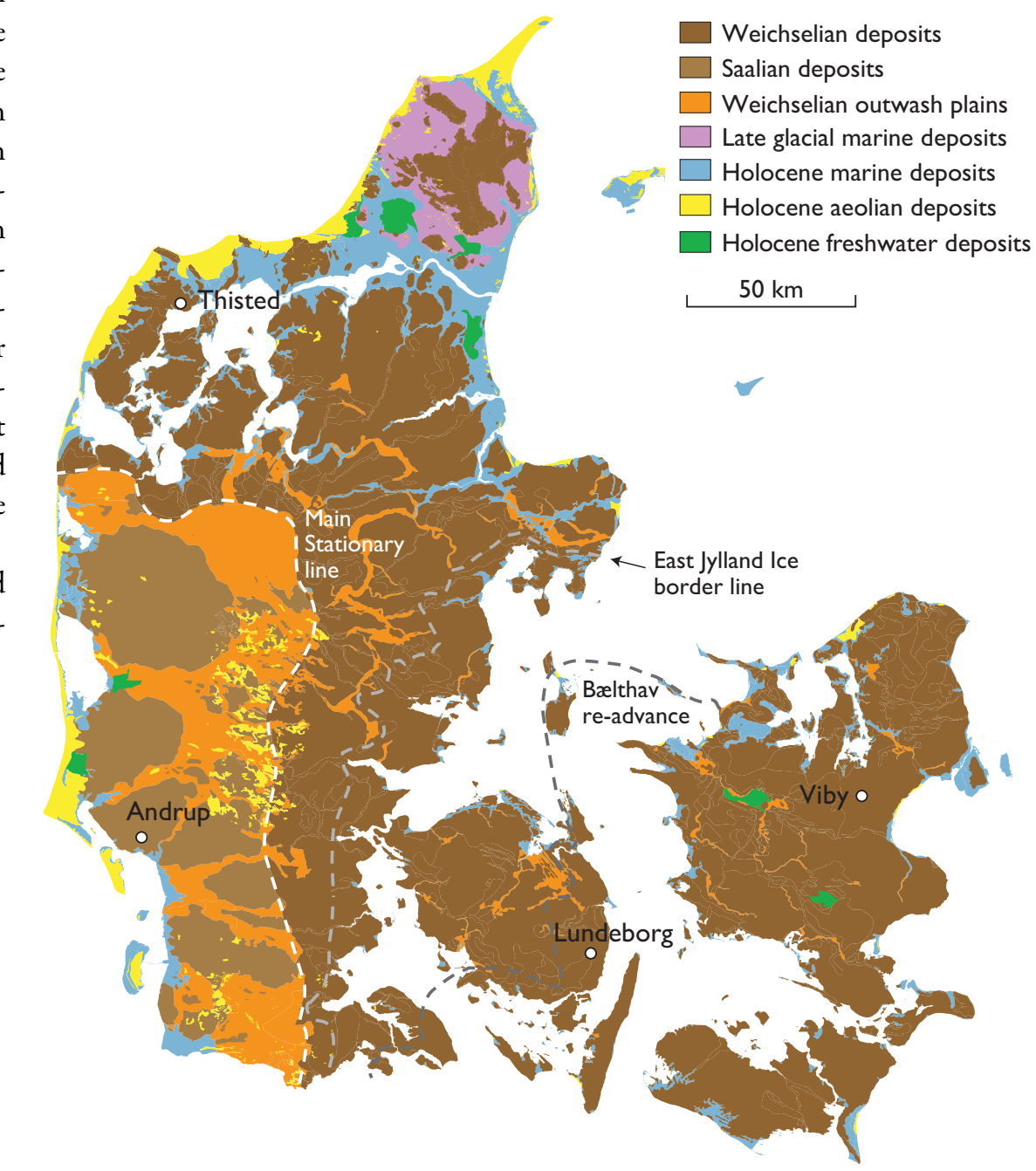




\section{Geological setting}

Clayey and sandy tills have been analysed for uranium, radium and radon content at the four localities Viby, Lundeborg, Thisted and Andrup (Fig. 1). The Andrup locality is situated outside the limit of the Weichselian glaciation and the till is considered to be of Saalian age deposited by a Warthe ice advance about 180 000-160 000 years ago (Houmark-Nielsen 2007). The Thisted, Lundeborg and Viby localities are located inside the maximum extent of Weichselian glaciacion and the tills are referred to the Weichselian. A relatively thin layer of till covers limestone and chalk deposits at Thisted. The till is regarded as deposited during the late Weichselian by the Norwegian advance or from the main glacial advance from the north-east about 25 000-20 000 years ago (Gry 1979). At Lundeborg and Viby the latest glacial advances are the East Jylland advance and the Bælthav re-advance about 19000 years ago. In sections close to the Lundeborg locality the slightly older Mid Danish Till, deposited during the North-East advance, is seen below the till from the Young Baltic advance. Some of the borehole samples may represent the Mid Danish Till (Houmark-Nielsen \& Kjær 2003).

\section{Materials and methods}

Trenches were excavated at the four localities down to a depth of $c .2 \mathrm{~m}$ into till deposits (Fig. 2). The sections were described with respect to lithology, structures and macropores, and samples of the clayey and sandy till units were collected at each locality. Five 5-6 m deep boreholes were drilled with an 8 inch twist auger close to the excavations. The nearly undisturbed till samples were described, and samples were collected at $30 \mathrm{~cm}$ intervals. The samples from the excavations had a weight of at least 500-1000 g, and those from the boreholes $300-500 \mathrm{~g}$.

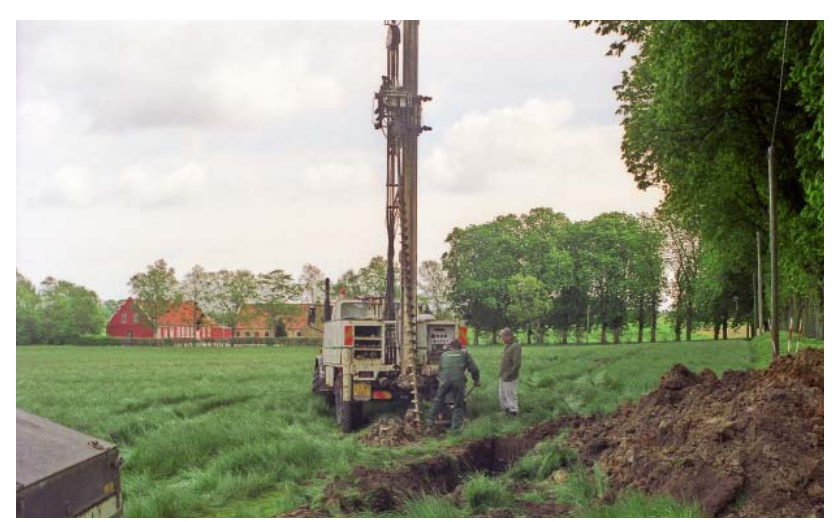

Fig. 2. Field investigations at the Lundeborg locality. Drilling close to the excavated trench.
A total of 155 samples were collected, with each sample consisting of two subsamples. One subsample was collected in a sealed plastic bin for radon analysis, and the other was analysed for chemical compounds including uranium and radium. Uranium was measured by instrumental neutron activation analysis at Activation Laboratories LTD and radium by a germanium detector at the National Institute of Radiation Protection. The radon emanation rate was measured by the closed-chamber method using $\mathrm{ZnS}(\mathrm{Ag})$ scintillation cells at Risø National Laboratory, Danish Technical University. Prior to the radon analyses the samples were fragmented. The purpose was to increase the surface area of the sediment to promote the release of radon produced by radium decay. In addition to the chemical analyses, grain-size distribution, clast composition, organic content and water content were analysed at GEUS immediately after sampling.

\section{Results and discussion}

This paper focuses on the measured radon emanation rates related to the weathering and redox (reduction-oxidation) conditions in the tills and the age difference between the tills at the four localities.

Till composition. The investigated tills are heterogeneous sediments with a matrix consisting of up to $20 \%$ clay, c. $70 \%$ silt and sand, and $4-10 \%$ gravel and stones. The clasts normally consist of Norwegian and Swedish basement rocks, quartz, Danish chert and limestone fragments. The matrix is a mixture of crushed basement rocks and local sediments dominated by quartz, feldspar, mica, smectite, kaolinite and illite. As a consequence of the heterogeneous sediment types uranium and radium are related to the source material and not uniformly distributed.

Weathering and redox conditions. The upper $0-3 \mathrm{~m}$ of the till profiles have been subject to weathering after the last deglaciation (Weichselian: Thisted, Lundeborg and Viby; Saalian: Andrup). Rainwater has percolated through pores in the till and caused decomposition and leaching of clay minerals, limonite and $\mathrm{CaCO}_{3}$. Measurements of the $\mathrm{CaCO}_{3}$ content show deep weathering at Andrup and nearly none at Viby.

Most till profiles in Denmark have an upper, yellow-brown coloured, oxidised zone and a lower, olive-grey-reduced zone separated by a redox interface. At Andrup the redox interface coincides with the $\mathrm{CaCO}_{3}$ leaching boundary, while at Lundeborg it is situated in the oxidised zone. At Viby only slight $\mathrm{CaCO}_{3}$ leaching has occurred in the top of the profile.

The redox zones are seen in the sections at Andrup, Lunderborg and Viby. In Table 1 the measured uranium and radium content and radon emanation rates are shown in relation to their occurrence in the two redox zones. The development 
Table 1. Uranium and radium contents and radon emanation rates at the four localities

\begin{tabular}{|c|c|c|c|c|c|c|c|}
\hline Locality & Lithology & Age & $\begin{array}{l}\text { Uranium } \\
\text { (ppm) }\end{array}$ & $\begin{array}{l}\text { Radium } \\
\text { (oxidised) } \\
\text { Bq/kg }\end{array}$ & $\begin{array}{c}\text { Radium } \\
\text { (reduced) } \\
\mathrm{Bq} / \mathrm{kg}\end{array}$ & $\begin{array}{c}\text { Radon } \\
\text { (oxidised) } \\
\text { Atom } / \mathrm{kg} / \mathrm{s}\end{array}$ & $\begin{array}{c}\text { Radon } \\
\text { (reduced) } \\
\text { Atom } / \mathrm{kg} / \mathrm{s}\end{array}$ \\
\hline \multirow[t]{2}{*}{ Viby } & Sandy till & Weichselian & $1.4-2.6$ & $22.4-24.5$ & - & 7.9-11.3 & - \\
\hline & Clayey till & $\sim 18 \mathrm{ka}$ & & $17.6-26.1$ & $22.1-35.9$ & $5.2-13.9$ & $4.5-6.7$ \\
\hline \multirow[t]{2}{*}{ Lundeborg } & Sandy till & Weichselian & 1.1-1.9 & 18.5 & - & 7.3 & - \\
\hline & Clayey till & $\sim 18 \mathrm{ka}$ & & $13.8-24.9$ & $14.8-15.5$ & $7.3-15.6$ & $3.2-6.8$ \\
\hline \multirow[t]{3}{*}{ Thisted } & Sandy till & Weichselian & $0.5-1.6$ & $18.7-24.7$ & - & $7.5-10.4$ & - \\
\hline & Clayey till & $\sim 23 \mathrm{ka}$ & & 14.1 & - & 13.6 & - \\
\hline & Limey till & & & $1.2-6.6$ & - & $0.9-1.5$ & - \\
\hline Andrup & Clayey till & $\begin{array}{l}\text { Saalian } \\
\sim 170 \mathrm{ka}\end{array}$ & $1.2-1.9$ & $14.1-20.6$ & $12.6-19.1$ & $6.2-10.6$ & $2.6-3.7$ \\
\hline
\end{tabular}

75 samples were analysed in total

of the redox zones depends on chemical and physical processes and therefore the behaviour of $\mathrm{U}$ and $\mathrm{Ra}$ in the zones is related to these processes. In the oxidised zone oxygen and for example nitrate influence the compositions of the minerals. The original uranium contained in the minerals is oxidised and mobilised, whereas the decay product radium is less mobile. Radium is not uniformly distributed and often precipitated as films or crusts at the rim of the sediment pores between grains of clay minerals, limonite and $\mathrm{CaCO}_{3}$ where it produces radon. In the reduced zone the U-bearing minerals are more stable and emit less radon (Ball et al. 1991).

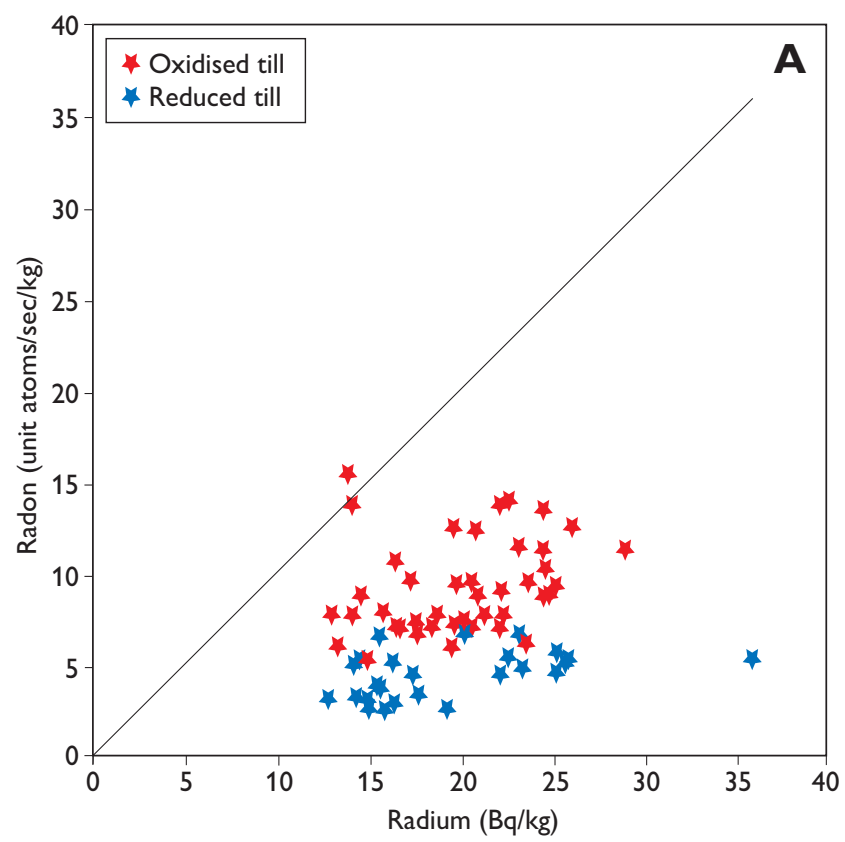

The investigation demonstrates larger rates of radon emanation in the oxidised zone than in the reduced zone (Table 1). The radium and radon levels seem to be comparable with the measurements reported_by Damkjær \& Korsbech (1985). The radium concentration is fairly constant in the two redox zones (Table 1). The higher radon content in the oxidised zone may be caused by enhanced emanation conditions. It may be due to opening of mineral pores in the oxidised zone as a result of an increase in number and size of macro-pores and higher permeability than in the reduced zone where radon is often trapped in smaller pores.

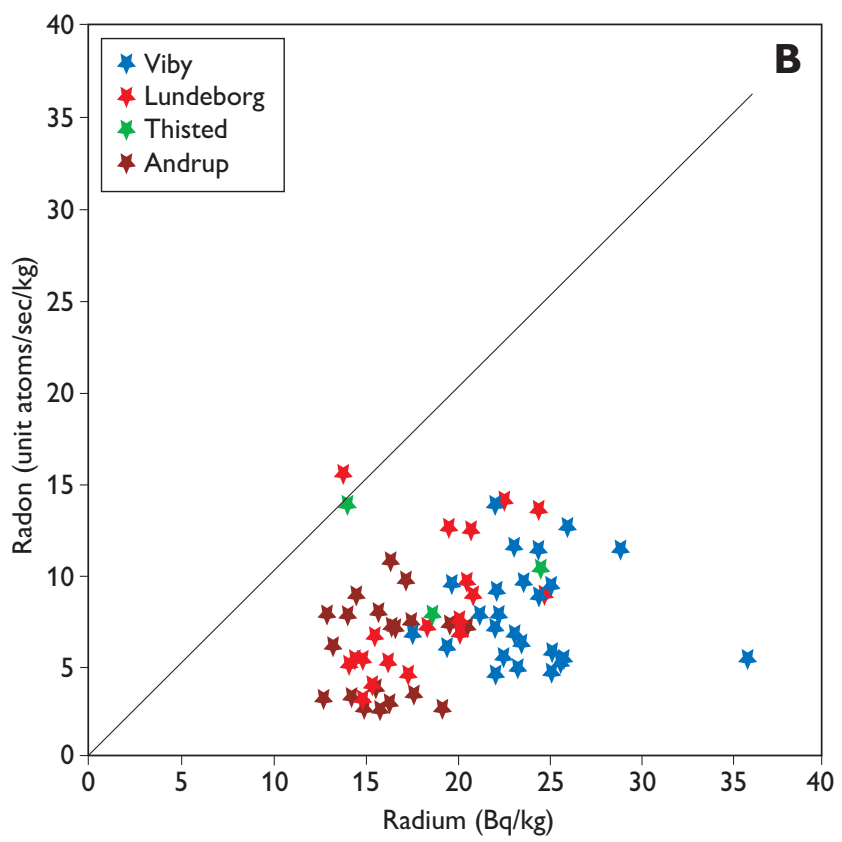

Fig. 3. Comparison between radium content and radon emanation rates in Danish tills. A radium content of $1 \mathrm{~Bq} \mathrm{~kg}^{-1}$ yields a total radon production rate of 1 atom $\mathrm{kg}^{-1} \mathrm{sec}^{-1}$. This relationship is represented by the diagonal line in the diagrams. A: Plot of radium versus radon based on values for oxidised and reduced zones at the four studied localities. B: Plot of radium versus radon in the oxidised and reduced zones at the four localities. One sample seems to produce more radon than the radium content can explain. The value is $15616 \pm 1710$ atoms $\mathrm{kg}^{-1} \mathrm{sec}^{-1}$. 
Water content is also a factor to consider because it influences the distance the radon atoms have to travel to enter the pores. According to Damkjær \& Korsbech (1985) up to $17 \%$ of water in the pores will increase the emanation rate. The water content in the tills is mostly below $17 \%$ but above the ideal content of $3-7 \%$, and the content is slightly higher in the oxidised than in the reduced zone.

Radon emanation rates in the two redox zones appear to be independent of the geographical distribution of the till. In Fig. 3 the distribution of radon and radium is seen in relation to redox zones. The radon emanation rates in both zones are lower than the corresponding radium content, which indicates that only some of the radon leaves the mineral grains and enters the pores of the till. The reduced zone has lower radon emanation rates than the oxidised zone in nearly all cases.

Transport conditions. After the radon atoms have moved into the pores the transport is controlled by the porosity and permeability of the till. Till has a relatively high matrix porosity but the occurrence of macro-pores in the form of roots, fractures and faults is of considerable importance. Macropores are most frequent in the oxidised zone. They were found in all sections, and their distribution explains the large difference in hydraulic conductivity between the two zones. The oxidised zone shows systematically decreasing values of hydraulic conductivity from the surface to a depth of $2-4 \mathrm{~m}$ (the redox interface) from $10^{-3} \mathrm{~m} / \mathrm{s}$ to $10^{-11} \mathrm{~m} / \mathrm{s}$. Below the redox interface the hydraulic conductivity varies unsystematically from $10^{-10} \mathrm{~m} / \mathrm{s}$ to $10^{-5} \mathrm{~m} / \mathrm{s}$ (Nilsson \& Klint 2009).

Age relationship. A comparison between radon and radium values from the Saalian locality (Andrup) and the Weichselian localities (Thisted, Lundeborg and Viby) show differences that appear to be related to the age of the till. Figure 3 shows that average radon emanation rates generally increase from the Saalian till to the younger Weichselian till and it is seen that there is a clear difference between the Andrup and Viby localities. This is probably because the till at Andrup has been exposed to weathering and precipitation for a longer time than that at Viby. These processes have led to removal of uranium and fixed radium at a lower level than seen for the Weichselian till. The in-situ radon producing radioactive decay in the Saalian till lasted more than 150000 years longer than in the Weichselian till. Another explanation could be different bulk mineralogy in the tills deposited by ice advances of different ages.

\section{Final remarks}

Our investigation indicates that radon emanation rates in till are higher in the oxidised zone than in the reduced zone at all four localities and that they are higher in Weichselian till than in Saalian till. However, only limited data are available for this conclusion. Many Danish dwelling houses are built on clayey tills, and the new information concerning the redox conditions is important when evaluating transport and impact of radon into dwelling houses and the risk of exposure to inhalation of radon in Denmark.

\section{Acknowledgement}

The Ministry of Health and Prevention is thanked for financial support.

\section{References}

Andersen, C.E., Ulbak, K., Damkjær, A. \& Gravesen, P. 2001: Radon i danske boliger. Kortlægning af lands-, amts- og kommuneværdier, 132 pp. Copenhagen: Sundhedstyrelsen, Statens Institut for Strålehygiejne.

Andersen, C.E., Raaschou-Nielsen, O., Andersen, H.P., Lind, M., Gravesen, P., Thomsen, B. \& Ulbak K. 2006: Prediction of ${ }^{222} \mathrm{Rn}$ in Danish dwellings using geology and house construction information from central databases. Radiation Protection Dosimetry 27, 10-21.

Ball, T.K., Cameron, D.G., Colman, T.B. \& Roberts, P.D. 1991: Behaviour of radon in the geological environment: a review. Quarterly Journal of Engineering Geology and Hydrogeology 24, 169-182.

Damkjær, A. \& Korsbech, U. 1985: Measurement of the emanation of radon-222 from Danish soils. The Science of the Total Environment 45, 343-350.

Gravesen, P., Jakobsen, P.R. \& Kelstrup, N. 1996: Radon i danske jordarter II. Undersøgelser og konklusioner. Danmarks og Grønlands Geologiske Undersøgelse Rapport 1996/78, 113 pp.

Gry, H. 1979: Beskrivelse til geologisk kort over Danmark. Kortbladet Løgstør. Kvartære aflejringer 1:100 000/1:50 000. Danmarks Gelogiske Undersøgelse I. Række 26, 58 pp.

Houmark-Nielsen, M. 2007: Extent and age of Middle and Late Pleistocene glaciations and periglacial episodes in southern Jylland, Denmark. Bulletin of the Geological Society of Denmark 55, 9-35.

Houmark-Nielsen, M. \& Kjær, K. 2003: Southwest Scandinavia, 40-15 kyr BP: palaeogeography and environmental change. Journal of Quaternary Science 18, 769-786.

Nazaroff, W.W. 1992: Radon transport from soil to air. Reviews of Geophysics 30, 137-160.

Nilsson, B. \& Klint, K.E. 2009: Bilag 7. Sammenstilling af data fra hydrauliske undersøgelser i moræneler - videnstatus. In: Gravesen, P. \& Rosenberg, P. (eds): Særligt pesticidfølsomme lerområder: datagrundlag og mulige veje mod zonering, KUPA, 70 pp. + appendices (report). Copenhagen: Geological Survey of Denmark and Greenland.

Raaschou-Nielsen, O., Andersen, C.E., Andersen, H.P., Gravesen, P., Lind, M., Schüz, J. \& Ulbak, K. 2008: Domestic radon and childhood cancer in Denmark. Epidemiology 19, 536-543.

Sundhedsstyrelsen 1987: Radon-Boliger-Strålingsdosis-Lungekræftrisiko, 14 pp. Copenhagen: Statens Institut for Strålehygiejne. 